\title{
Perbandingan Model Pembelajaran Mata Kuliah Metodologi Penelitian Dalam Meningkatkan Kompetensi Mahasiswa
}

Oleh:

\author{
Ahmad Danu Syaputra, Fitria, Dheo Rimbano \\ Universitas Bina Insan Lubuklinggau \\ ahmaddanusyaputra7@gmail.com
}

\begin{abstract}
The lack of analytical, critical and creative attitudes occurs because of the mindset of students or their teaching staff. This explanation is the basis for why researchers try to study with the aim of making a Comparative Study Model for Research Methodology Courses in Improving Student Competencies to Arrange Final Projects in PTS (Private Universities) in Lubuklinggau City and Musi Rawas Districts. The research population of 5,604 students spread across well-known private Universities in Lubuklinggau City and Musi Rawas District, researchers took a sample of $1 \%$, with a uniform distribution. The researcher uses the frequency crosstab analysis (cross percentage), for the comparative type the researcher uses the technique of One Sample T Test, Independent Sample T Test, and One Way Anova. Research results (1) There are differences in each PTS in the application of learning models in general; (2) There is no difference in each PTS in the application of specific learning models, both the parametric approach model and the micromorph approach model; (3) There are differences in student competencies in each in terms of physical competence; and (4) There are no differences in student competencies in each in terms of intellectual competence; personal; social; and spiritual.
\end{abstract}

Keywords : Learning Models; Competence;

\begin{abstract}
Abstrack
Banyaknya hasil penelitian (skripsi) mahasiswa antar perguruan tinggi yang sejenis, hal ini menjadi pertanyaan sendiri bagi peneliti kenapa ini terjadi?. Kurangnya sikap analitis, kritik dan kreatif apakah terjadi karena dari pola pikir mahasiswa atau Tenaga Pendidiknya Penjelasan tersebut menjadi dasar kenapa peneliti mencoba mengkaji sebuah penelitian dengan tujuan untuk melakukan perbandingan Model Pembelajaran Mata Kuliah Metodologi Penelitian Dalam Meningkatkan Kompetensi Mahasiswa Untuk Menyusun
\end{abstract}

FOKUS : Jurnal Kajian Keislaman dan Kemasyarakatan Vol. 4, No. 2, 2019

LPPM Institut Agama Islam Negeri (IAIN) Curup - Bengkulu

Available online: http://journal.staincurup.ac.id/index.php/JF

p-ISSN 2548-334X, e-ISSN 2548-3358 
Tugas Akhir di PTS (Perguruan Tinggi Swasta) Wilayah Kota Lubuklinggau Dan Kabupaten Musi Rawas. Populasi penelitian sebanyak 5.604 mahasiswa yang tersebar di PTS ternama di Kota Lubuklinggau dan Kabupaten Musi Rawas, peneliti mengambil sampel sebanyak $1 \%$ yakni sejumlah 600 dengan sebaran merata. Peneliti menggunakan analisis crosstab frekuensi (persentase silang), untuk tipe komparatif peneliti menggunakan teknik analisis One Sample T Test, Independent Sample T Test, dan One Way Anova. Hasil penelitiannya (1) Terdapat perbedaan pada tiap PTS dalam penerapan model pembelajaran secara umum; (2) Tidak terdapat perbedaan pada tiap PTS dalam penerapan model pembelajaran secara spesifik, baik model pendekatan secara paramorf maupun model pendekatan secara mikromorf; (3) Terdapat perbedaaan kompetensi mahasiswa pada tiap dari sisi kompetensi fisik; dan (4) Tidak terdapat perbedaan kompetensi mahasiswa pada tiap dari sisi kompetensi intelektual; pribadi; sosial; dan spiritual.

Kata Kunci : Model Pembelajaran dan Kompetensi

\section{PENDAHULUAN}

Ada banyaknya kesamaan jenis penelitian ketika menyusun sebuah tugas akhir atau skripsi mahasiswa antar perguruan tinggi di wilayah Kota Lubuklinggau dan Kabupaten Musi Rawas, sedangkan kita ketahui sebetulnya sangat banyak jenis penelitian yang dapat diambil dari pertanyaan-pertanyaan berasal dari masalah yang ada kemudian dapat diangkat menjadi sebuah tugas akhir. Menjadi sebuah pertanyaan kenapa hal ini dapat terjadi? Apakah kurangnya sikap analitis, kritik dan kreatif apakah terjadi karena dari pola pikir mahasiswa atau Tenaga Pendidiknya?

Dari beberapa perguruan tinggi ternama yang ada di wilayah Kota Lubuklinggau dan Kabupaten Musi Rawas terdapat total keseluruhan mahasiswa yang masih aktif berjumlah 5.604 mahasiswa yang terdiri dari perguruan tinggi STIE MURA Lubuklinggau, STIMIK MURA Lubuklinggau, STKIP Lubuklinggau, dan UNMURA. Hasil kajian dari skripsi mahasiswa yang peneliti lakukan dengan mengambil skripsi yang terkumpul di perpustakaan tahun 2017 perguruan tinggi berada yang tergambar dari tabel dibawah sebagai berikut;

Tabel 1. Jenis Skripsi Salah Satu Prodi di PTS Kota Lubuklinggau

\begin{tabular}{|c|l|c|c|}
\hline No & Jenis Penelitian & Banyaknya & Persentase \\
\hline $\mathbf{1}$ & Kuantitatif - Asosiatif & 110 & $77 \%$ \\
\hline $\mathbf{2}$ & Kuantitatif - Deskriptif & 37 & $23 \%$ \\
\hline $\mathbf{3}$ & Kualitatif - Studi Kasus & 14 & $9 \%$ \\
\hline \multicolumn{2}{|c|}{ Jumlah } & $\mathbf{1 6 1}$ & \\
\hline
\end{tabular}


Data menunjukkan bahwa terdapat kesamaan Jenis Penelitian untuk jenis Kuantitatif - Asosiatif sebesar 77\% sisanya hanya ada 2 (Dua) Jenis Penelitian lainnya, apabila kita maknai data tersebut, Jumlah riset (Skripsi) sebanyak 161, dari 161 Skripsi tersebut hanya dibuat berdasarkan 3 (Tiga) Jenis Penelitian, sedangkan kita ketahui sangat banyak Jenis Penelitian yang dapat digunakan. Pertanyaannya kenapa hal ini dapat terjadi, apabila kita lihat dari sisi mahasiswanya, maka mahasiwa mempunyai kelemahan dalam dirinya (Kompetensi) : (1) Lemah dalam pemahaman baik tentang konsep dasar, penyusunan teori maupun aplikasi sebuah proses penelitian; (2) Kurang bisa memaknai penelitian yang relevan atau terdahulu; dan (3) Kurangnya sikap analitis, kritik dan kreatif dari pola pikir mahasiswa. namun apabila kita berpikir dari sisi Tenaga Pendidiknya, maka dapat kita katakan bahwa Tenaga Pendidik yang memberikan Mata Kuliah ini juga dapat dikatakan gagal, dalam memberikan pemahaman kepada Mahasiswa tentang Metodologi Penelitian, kelemahan ini dapat berupa : (1) Tidak jelas capaian pembelajaran Mata Kuliah tersebut; (2) Model Pembelajaran yang tidak tepat; dan (3) Kompetensi Tenaga Pendidik itu sendiri yang memang lemah. Maka atas dasar tersebut Peneliti mencoba untuk mengetahui dan menganalisis Bagaimana Penerapan dan Perbedaan Model Pembelajaran Mata Kuliah Metodologi Penelitian Dalam Meningkatkan Kompetensi Mahasiswa Untuk Menyusun Tugas Akhir di PTS Wilayah Kota Lubuklinggau Dan Kabupaten Musi Rawas.

Terdapat beberapa penelitian yang peneliti jadikan rujukan, diantaranya: Efendi dengan judul "Integrasi Pembelajaran Active Learning dan Internet-Based Learning dalam Meningkatkan Keaktifan dan Kreativitas Belajar". Hasil penelitian bahwa Integrasi pembelajaran active learning dan internet-based learning yang dapat meningkatkan keaktifan dan kreativitas belajar mahasiswa di Prodi PGMI STAIN Ponorogo dalam bentuk penggunaan strategi pembelajaran yang mengembangkan kemampuan berpikir analitis dari mahasiswa yaitu information search dan role play pada mata kuliah IPS1, Jigsaw dan demonstration pada mata kuliah Strategi Belajar Mengajar, concept mapping dan peer teaching pada mata kuliah Pembelajaran IPA di MI. Di samping itu, untuk mendukung proses pembelajaran, baik dosen maupun mahasiswa memanfaatkan situs web seperti yahoo, google, wikipedia, youtube dan edmodo. Dalam hal ini, internet dipakai baik sebagai media maupun sumber belajar.

Penelitian selanjutnya Zulpadrianto \& Husna "Perbandingan Kompetensi Mahasiswa Yang Diberi Resitasi Peta Konsep Dengan Menjawab Pertanyaan Sebelum Melaksanakan Praktikum Fisika Dasar Di Laboratorium Fisika Dasar STKIP PGRI Sumatera Barat" Bahwa terdapat 
perbedaan kompetensi mahasiswa yang diberi Resitasi Peta Konsep dengan Menjawab pertanyaan sebelum praktikum pada ranah kognitif dan ranah afektif.

Suryatun dengan judul "Studi Perbandingan Kompetensi Praktik Kelistrikan Otomotif Mahasiswa Lulusan SMA dan SMK pada Program Studi Pendidikan Teknik Mesin JPTK FKIP UNS" Bahwa terdapat perbedaan kompetensi mahasiswa Program Studi PTM JPTK FKIP UNS angkatan tahun 2011 antara lulusan dari SMA dan SMK pada mata kuliah Praktik Kelistrikan Otomotif.

Situmorang dengan judul "Desain Model Pembelajaran Based Learning Dalam Peningkatan Kemampuan Konsep Mahasiswa Semester Tiga Jurusan Pendidikan Matematika Fkip-Uhn Medan" bahwa tidak terdapat interaksi antara pendekatan pembelajaran pendekatan PBL dan PK dan kemampuan awal matematika siswa (tinggi, sedang dan rendah) terhadap pemahaman konsep matematika matematik. Berdasarkan hasil penelitian ditemukan bahwa interaksi pembelajaran dengan menggunakan PBL sangat mempengaruhi peningkatan kemampuan pemahaman konsep matematika siswa untuk kategori rendah.

Terakhir penelitian oleh Purnomo dan Mawarsari dengan judul "Peningkatan Kemampuan Pemecahan Masalah Melalui Model Pembelajaran Ideal Problem Solving Berbasis Project Based Learning". Dihasilkan perangkat pembelajaran yaitu buku ajar materi persamaan kudrat, peluang, trigonometri, turunan dan program linier yang baik. Implementasi model pembelajaran IDEAL problem solving berbasis PBL dapat meningkatkan kemampuan pemecahan masalah.

Terkait dengan kompetensi Sedarmayanti, (2018); Sedarmayanti \& Pd, (2001); dan Sedarmayanti, (2007) memberikan berbagai konsep tentang Kompetensi, sebagai berikut:

1) Konsep luas, memuat kemampuan mentransfer keahlian dan kemampuan kepada situasi baru dalam wilayah kerja, menyangkut organisasi dan perencanaan pekerjaan, inovasi dan mengatasi aktivitas rutin, kualitas efektivitas personel yang dibutuhkan di tempat berkaitan dengan rekan kerja, manajer serta pelanggan;

2) Kemampuan dan kemauan melakukan tugas; Dimensi prilaku yang mempengaruhi kinerja; Karakteristik individu apapun yang dapat dihitung dan diukur secara konsisten, dapat dibuktikan untuk membedakan secara signifikan antara kinerja efektif dengan tidak efektif;

3) Kemampuan dasar dan kualitas kinerja yang diperlukan untuk mengerjakan pekerjaan dengan baik;

4) Bakat, sifat, dan keahlian individu apapun yang dapat dibuktikan, dapat dihubungkan dengan kinerja efektif dan baik sekali. 
Berdasarkan makna diatas penulis dapat menjelaskan bahwa kompetensi merupakan bagian dari kepribadian yang mendalam dan melekat pada seseorang dengan perilaku yang dapat diprediksi pada berbagai keadaan dan tugas pekerjaan yang akan dihadapi.

Irham, (2016) menjelaskan dalam bukunya bahwasannya kompetensi itu terbagi menjadi dua yakni (1) Threshold Competencies merupakan kompetensi dasar yang harus dimiliki oleh orang yang harus termiliki. dan (2) Differentiating Competencies merupakan sebuah kompetensi yang dimiliki oleh seseorang yang membedakan ia dengan orang lain. Selanjutnya Kunandar, (2007); dan Zendrato, (2016) membagi kompetensi menjadi 5 (lima) bagian yakni:

1) Kompetensi Intelektual, yaitu berbagai perangkat pengetahuan yang ada pada diri individu yang diperlukan untuk menunjang kinerja;

2) Kompetensi Fisik, yaitu perangkat kemampuan fisik yang diperlukan untuk pelaksanaan tugas;

3) Kompetensi Pribadi, yaitu perangkat perilaku yang berkaitan dengan kemampuan individu dalam mewujudkan diri, transformasi diri, identitas diri dan pemahaman diri;

4) Kompetensi Sosial, yaitu perangkat perilaku tertentu yang merupakan dasar dari pemahaman diri sebagai bagian yang tidak terpisahkan dari lingkungan sosial;

5) Kompetensi Spiritual, yaitu pemahaman, penghayatan serta pengamalan kaidah-kaidah keagamaan.

Sedangkan Model pembelajaran adalah suatu abstraksi yang dapat digunakan untuk membantu memahami sesuatu yang tidak bisa dilihat atau dialami langsung (Oka, 2017; Saputri \& Wilujeng, 2017). Terdapat dua macam model yang lazim dikenal dalam pembelajaran yakni model mikromorf dan model paramorf. mikromorf adalah model secara visual, nyata secara fisik. sedangkan paramorf adalah model simbolik yang biasanya menggunakan deskripsi verbal. 


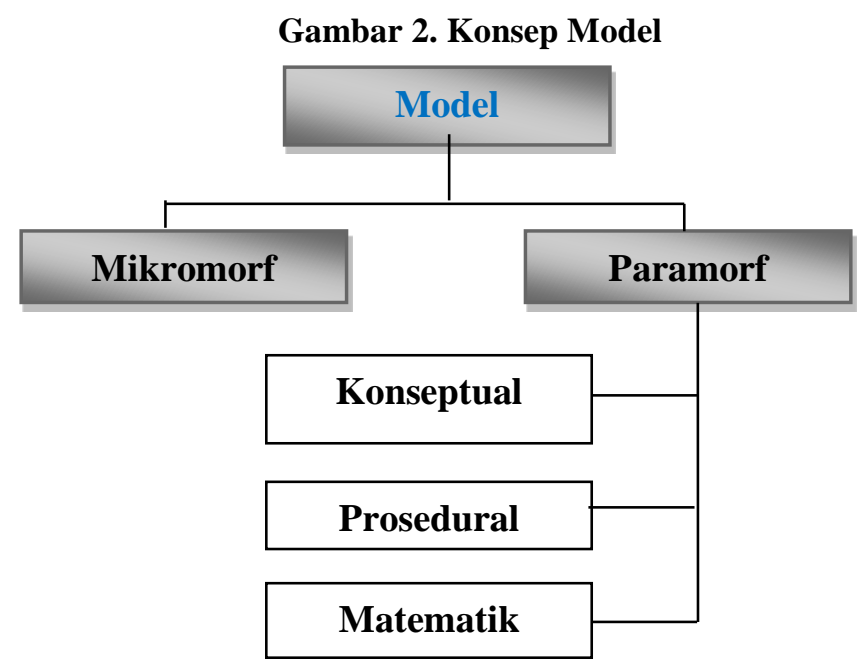

Sumber: Oka, (2017)

Penelitian ini menggunakan metode eksperimen. Kemudian peneliti juga menggunakan metode komparatif untuk menyelidiki hubungan salah satu variabel dengan variabel lainnya. Populasi penelitian sebanyak 5.604, untuk memudahkan peneliti dalam mengambil sampel, maka peneliti menggunakan bantuan tabel isaac dan michael (Wahyudi, 2017) N sebanyak 5.604 (dibulatkan peneliti menjadi 6.000) dengan tingkat kesalahan $1 \%$ maka didapatkan sampel sebanyak 598, untuk membuatnya rata maka sampel sebanyak 600 sampel dengan sebaran merata di objek penelitian. Metode analisa data yang digunakan peneliti adalah analisis crosstab frekuensi (persentase silang), untuk tipe komparatif peneliti menggunakan teknik analisis One Sample T Test, Independent Sample T Test, dan One Way Anova.

\section{HASIL DAN PEMBAHASAN HASIL}

\section{A. Uji Coba Instrumen Penelitian}

Sugiyono, (2006; 2005; 2015) mengatakan instrumen yang valid berarti alat ukur yang digunakan untuk mendapatkan data (mengukur) itu valid. Valid berarti instrumen tersebut dapat digunakan untuk mengukur apa yang seharusnya diukur. Sedangkan, instrumen yang reliabel adalah instrumen yang apabila digunakan beberapa kali untuk mengukur objek yang sama, akan menghasilkan data yang sama. Apabila instrumen yang diuji cobakan hailnya valid dan reliabel, maka diharapkan hasil penelitian juga nantinya akan menjadi valid dan reliabel. Hasil penelitian yang valid apabila terdapat kesamaan antara data yang terkumpul dengan data yang 
sesungguhnya terjadi pada objek yang diteliti, sedangkan hasil penelitian yang reliabel apabila terdapat kesamaan data dalam waktu yang berbeda.

Tabel 4. Reliabilitas Data

\begin{tabular}{|l|c|c|c|c|}
\hline \multicolumn{1}{|c|}{ Variabel } & $\begin{array}{c}\text { Cronbach' } \\
\text { s Alpha }\end{array}$ & $\begin{array}{c}\mathrm{R} \\
\text { tabel }\end{array}$ & Ket & $\begin{array}{c}\text { N of } \\
\text { Items }\end{array}$ \\
\hline Metode Pembelajaran MK Metodologi Penelitian & $\mathbf{0 , 9 5 3}$ & $\mathbf{0 . 3 8 0}$ & Reliabel & $\mathbf{2 5}$ \\
\hline Kompetensi Mahasiswa & $\mathbf{0 , 9 6 5}$ & $\mathbf{0 . 3 8 0}$ & Reliabel & $\mathbf{2 5}$ \\
\hline
\end{tabular}

Sumber : Pengolahan Data, 2019

Terlihat dari hasil uji reliability menggunakan SPSS pada tabel 4 menunjukkan nilai Cronbach's Alpha pada variabel Metode Pembelajaran MK Metodologi Penelitian dan Kompetensi Mahasiswa sebesar 0.953 dan 0.965 lebih besar dari nilai minimal Cronbach's Alpha, oleh karena itu disimpulkan semua variabel berada dalam status reliabel, yakni dapat dipercaya atau handal.

Tabel 5. Validitas Data Variabel Metode Pembelajaran MK Metodologi Penelitian

\begin{tabular}{|c|c|c|c|c|}
\hline No & Pernyataan Metode Pembelajaran & CITC & $\begin{array}{c}\mathbf{R} \\
\text { tabel }\end{array}$ & Ket \\
\hline 1 & $\begin{array}{l}\text { Dosen MK Metodologi Penelitian Saudara, Menjelaskan Rencana } \\
\text { Pembelajarannya. }\end{array}$ & $\mathbf{0 , 7 5 0}$ & $\mathbf{0 . 3 8 0}$ & Valid \\
\hline 2 & $\begin{array}{l}\text { Dosen MK Metodologi Penelitian Saudara, Menjelaskan Bahwa } \\
\text { Ia Menggunakan Sebuah Model/Teknik/Cara dalam } \\
\text { Melaksanakan Perkuliahannya. }\end{array}$ & $\mathbf{0 , 8 1 0}$ & $\mathbf{0 . 3 8 0}$ & Valid \\
\hline 3 & $\begin{array}{l}\text { Dosen MK Metodologi Saudara, Menggunakan Buku Teori Dan } \\
\text { Memperkenalkan Penulis Buku Tersebut. }\end{array}$ & 0,604 & $\begin{array}{l}.380 \\
.380\end{array}$ & Valid \\
\hline 4 & $\begin{array}{l}\text { Dosen MK Metodologi Saudara, Menggunakan Jurnal Ilmiah } \\
\text { Dan Memperkenalkan Penulis, Nama Jurnal, dan Peringkat } \\
\text { Jurnal Tersebut. }\end{array}$ & 0,688 & 0.380 & Valid \\
\hline 5 & $\begin{array}{l}\text { Dosen MK Metodologi Saudara Menggunakan Fasilitas (Internet, } \\
\text { Blog, E-learning, Portal, e-class, dan sejenisnya) dalam } \\
\text { melaksanakan Perkuliahan. }\end{array}$ & $-0,061$ & 0.380 & $\begin{array}{l}\text { Tidak } \\
\text { Valid }\end{array}$ \\
\hline 6 & $\begin{array}{l}\text { Saat memberikan kuliah. Dosen MK Metodologi Penelitian } \\
\text { Saudara, memberikan contoh Jurnal Penelitian yang lengkap. }\end{array}$ & 0,766 & 0.380 & Valid \\
\hline 7 & $\begin{array}{l}\text { Saat memberikan kuliah. Dosen MK Metodologi Penelitian } \\
\text { Saudara, memberikan contoh Proposal Penelitian dan Hasil Akhir } \\
\text { Karya Ilmiah yang lengkap. }\end{array}$ & 0,876 & $\mathbf{0 . 3 8 0}$ & Valid \\
\hline 8 & $\begin{array}{l}\text { Saat memberikan kuliah. Dosen MK Metodologi Penelitian } \\
\text { Saudara, menjalankan perkuliahan dengan pola mengikuti isi dari } \\
\text { Jurnal. }\end{array}$ & $\mathbf{0 , 8 0 0}$ & $\mathbf{0 . 3 8 0}$ & Valid \\
\hline 9 & $\begin{array}{l}\text { Saat memberikan kuliah. Dosen MK Metodologi Penelitian } \\
\text { Saudara, menjalankan perkuliahan dengan pola mengikuti isi dari } \\
\text { Proposal dan Hasil Akhir Karya Ilmiah. }\end{array}$ & $\mathbf{0 , 8 0 3}$ & $\mathbf{0 . 3 8 0}$ & Valid \\
\hline 10 & $\begin{array}{l}\text { Mahasiswa diberikan Tugas Menelaah (Review) Jurnal, saat } \\
\text { Perkuliahan Metodologi Penelitian. }\end{array}$ & 0,552 & 0.380 & Valid \\
\hline 11 & $\begin{array}{l}\text { Mahasiswa diberikan Tugas Menyusun Sebuah Proposal, saat } \\
\text { Perkuliahan Metodologi Penelitian. }\end{array}$ & $\mathbf{0 , 7 3 8}$ & 0.380 & Valid \\
\hline 12 & $\begin{array}{l}\text { Dosen Memberikan Contoh Simulasi Perhitungan Analisa Data } \\
\text { Jenis Penelitian Kuantitaif, Baik Menggunakan Bantuan Aplikasi } \\
\text { SPSS, EVIEWS, LISREL, AMOS, PLS maupun Tools Sejenisnya, }\end{array}$ & 0,758 & 0.380 & Valid \\
\hline
\end{tabular}




\begin{tabular}{|c|c|c|c|c|}
\hline No & Pernyataan Metode Pembelajaran & CITC & $\begin{array}{c}\mathbf{R} \\
\text { tabel }\end{array}$ & Ket \\
\hline & saat Perkuliahan Metodologi Penelitian. & & & \\
\hline 13 & $\begin{array}{l}\text { Dosen Memberikan Contoh Simulasi Analisa Data Jenis } \\
\text { Penelitian Kualitatif, Baik Menggunakan Bantuan Aplikasi } \\
\text { NVIVO, TDC, Smart Cloud, maupun Tools Sejenisnya, saat } \\
\text { Perkuliahan Metodologi Penelitian. }\end{array}$ & 0,647 & 0.380 & Valid \\
\hline 14 & $\begin{array}{l}\text { Mahasiswa diberikan sesi untuk melakukan presentasi (Baik hasil } \\
\text { Review Jurnalnya, Draf Propsoalnya, maupun Hasil simulasi } \\
\text { analisa datanya), saat Perkuliahan Metodologi Penelitian. }\end{array}$ & 0,674 & $\mathbf{0 . 3 8 0}$ & Valid \\
\hline 15 & $\begin{array}{l}\text { Dosen memberikan evaluasi atas presentasi (Baik hasil Review } \\
\text { Jurnalnya, Draf Propsoalnya, maupun Hasil simulasi analisa } \\
\text { datanya) yang dilakukan mahasiswa, saat Perkuliahan } \\
\text { Metodologi Penelitian. }\end{array}$ & 0,785 & 0.380 & Valid \\
\hline 16 & $\begin{array}{l}\text { Saat Perkuliahan MK Metodologi Penelitian, Dosen tersebut } \\
\text { menjelaskan Konsep-konsep dan definisi-definisi item yang } \\
\text { tergabung dalam sub bab MK Metodologi Penelitian (Misal, Sub } \\
\text { Bab 1 Latar Belakang, Sub bab } 2 \text { Perumusan Masalah, dan } \\
\text { seterusnya). }\end{array}$ & 0,751 & 0.380 & Valid \\
\hline 17 & $\begin{array}{l}\text { Saat Perkuliahan MK Metodologi Penelitian, Dosen tersebut } \\
\text { mengajarkan materi kuliah dengan menjelaskan melalui pola, } \\
\text { baik secara deduksi maupun induksi. }\end{array}$ & 0,707 & 0.380 & Valid \\
\hline 18 & $\begin{array}{l}\text { Dosen memberikan logika logika yang tepat, saat mengajarkan } \\
\text { MK Metodologi Penelitian }\end{array}$ & $\mathbf{0 , 8 5 5}$ & 0.380 & Valid \\
\hline 19 & $\begin{array}{l}\text { Dosen memberikan contoh analisis tentang masing masing sub } \\
\text { item dalam MK Metodologi Penelitian dengan kejadian yang up } \\
\text { date atau hot issue. }\end{array}$ & 0,757 & 0.380 & Valid \\
\hline 20 & $\begin{array}{l}\text { Dosen menjabarkan teori teori yang relevan dalam menjelaskan } \\
\text { masing masing sub item dalam MK Metodologi Penelitian. }\end{array}$ & $\mathbf{0 , 5 7 0}$ & $\mathbf{0 . 3 8 0}$ & Valid \\
\hline 21 & $\begin{array}{l}\text { Saat Perkuliahan MK Metodologi Penelitian, Dosen tersebut } \\
\text { memberikan langkah langkah disertakan contoh dalam membuat } \\
\text { sebuah proposal penelitian }\end{array}$ & 0,609 & 0.380 & Valid \\
\hline 22 & $\begin{array}{l}\text { Saat Perkuliahan MK Metodologi Penelitian, Dosen menjelaskan } \\
\text { dirinya yang telah pengalaman dalam melakukan sebuah } \\
\text { penelitian, dan menularkan pengalaman tersebut. }\end{array}$ & 0,776 & $\mathbf{0 . 3 8 0}$ & Valid \\
\hline 23 & $\begin{array}{l}\text { Dosen memberikan deskripsi. Tentang hubungan hubungan teori } \\
\text { yang digunakan sebagai dasar sebuah penelitian. }\end{array}$ & 0,660 & $\mathbf{0 . 3 8 0}$ & Valid \\
\hline 24 & $\begin{array}{l}\text { Dosen memberikan deskripsi. Tentang hubungan hubungan } \\
\text { jurnal yang digunakan sebagai dasar sebuah penelitian. }\end{array}$ & 0,768 & 0.380 & Valid \\
\hline 25 & $\begin{array}{l}\text { Saat Perkuliahan MK Metodologi Penelitian, dosen tersebut juga } \\
\text { memberikan materi tambahan tentang ilmu ilmu statistik di dalam } \\
\text { sebuah penelitian. }\end{array}$ & $\mathbf{0 , 7 3 5}$ & $\mathbf{0 . 3 8 0}$ & Valid \\
\hline
\end{tabular}

Sumber : Pengolahan Data, 2019

Berdasarkan output Validitas Data Variabel Metode Pembelajaran MK Metodologi Penelitian pada tabel 5 diatas diketahui dari 25 item terdapat 24 item dinyatakan valid karena nilai $\mathrm{r}$ hitung lebih besar dari 0.3. Sedangkan terdapat 1 item pada item ke-5 dengan nilai $r$ hitung 0,061 lebih rendah dari 0.3 dan dinyatakan tidak valid. 
Tabel 6. Validitas Data Variabel Kompetensi Mahasiswa Saat Menyusun Karya

\begin{tabular}{|c|c|c|c|c|}
\hline \multicolumn{5}{|c|}{ Ilmiah } \\
\hline No & Pernyataan Kompetensi Mahasiswa & CITC & $\begin{array}{c}\mathbf{R} \\
\text { tabel }\end{array}$ & Ket \\
\hline 1 & $\begin{array}{l}\text { Dalam memberikan Kuliah, Dosen MK Metodologi Penelitian } \\
\text { Saudara memiliki pengetahuan yang luas. }\end{array}$ & 0,405 & 0.380 & Valid \\
\hline 2 & $\begin{array}{l}\text { Dosen MK Metodologi saudara, memberi tahu peringkat } \\
\text { SINTA (merupakan portal yang berisi tentang pengukuran } \\
\text { kinerja Ilmu Pengetahuan dan Teknologi yang meliputi antara } \\
\text { lain kinerja peneliti) dosen tersebut. }\end{array}$ & $\mathbf{0 , 5 3 5}$ & 0.380 & Valid \\
\hline 3 & $\begin{array}{l}\text { Dosen MK Metodologi Penelitian Saudara, memberi tahu H } \\
\text { Indeks Dirinya, baik H Index Google Scholar, ataupun H Index } \\
\text { Scopus. }\end{array}$ & 0,633 & 0.380 & Valid \\
\hline 4 & $\begin{array}{l}\text { Dosen MK Metodologi Penelitian Saudara, memberi tahu } \\
\text { bahwa dirinya pernah tembus Hibah Penelitian yang } \\
\text { diselenggarakan oleh Pemerintah. }\end{array}$ & 0,562 & 0.380 & Valid \\
\hline 5 & $\begin{array}{l}\text { Dosen MK Metodologi Penelitian Saudara, memberi tahu } \\
\text { tentang Publikasinya (Jurnalnya, HAKInya, dan Sejenisnya), } \\
\text { dan memberikan tipsnya kepada saudara. }\end{array}$ & 0,793 & 0.380 & Valid \\
\hline 6 & $\begin{array}{l}\text { Saat Perkuliahan MK Metodologi Penelitian, Dosen } \\
\text { mengajarkan bagaimana prilaku saling memahami, } \\
\text { mendengarkan, menanggapi, dan mengerti keterbatasan } \\
\text { keterbatasan, dalam sebuah proses penelitian. }\end{array}$ & 0,874 & 0.380 & Valid \\
\hline 7 & $\begin{array}{l}\text { Saat Perkuliahan MK Metodologi Penelitian, Dosen memberi } \\
\text { tahu, bahwa sebuah penelitian bertujuan utama untuk saling } \\
\text { memuaskan (Peneliti dan Objek) dengan dasar Kejujuran. }\end{array}$ & 0,775 & 0.380 & Valid \\
\hline 8 & $\begin{array}{l}\text { Saat Perkuliahan MK Metodologi Penelitian, Dosen } \\
\text { mengajarkan bahwa mahasiswa harus pandai dalam } \\
\text { mengendalikan diri, karena proses penelitian tidak hanya soal } \\
\text { akademis saja, namun juga soal mental. }\end{array}$ & 0,645 & 0.380 & Valid \\
\hline 9 & $\begin{array}{l}\text { Saat Perkuliahan MK Metodologi Penelitian, Dosen } \\
\text { memberikan contoh sikap bahwa mahasiswa harus percaya diri } \\
\text { penelitian yang dilakukannya pasti selesai. }\end{array}$ & $\mathbf{0 , 8 4 0}$ & 0.380 & Valid \\
\hline 10 & $\begin{array}{l}\text { Saat Perkuliahan MK Metodologi Penelitian, Dosen } \\
\text { mengajarkan bahwa mahasiswa harus mampu beradaptasi } \\
\text { dengan lingkungan saat melakukan sebuah penelitian. }\end{array}$ & 0,773 & 0.380 & Valid \\
\hline 11 & $\begin{array}{l}\text { Dosen MK Metodologi Penelitian Saudara, memiliki visual } \\
\text { dan penalaran yang tinggi, baik secara deduktif maupun secara } \\
\text { induktif saat memberikan kuliah. Sehingga berdampak kepada } \\
\text { semangat anda untu belajar meneliti. }\end{array}$ & $\mathbf{0 , 9 0 7}$ & 0.380 & Valid \\
\hline 12 & $\begin{array}{l}\text { Saat Perkuliahan MK Metodologi Penelitian, Dosen tersebut } \\
\text { memiliki tingkat kecerdasan diatas rata rata (Baik secara angka } \\
\text { maupun narasi) dibandingkan dosen dosen yang pernah } \\
\text { memberikan kuliah. Sehingga proses perkuliahan menjadi } \\
\text { hidup. }\end{array}$ & $\mathbf{0 , 7 2 0}$ & 0.380 & Valid \\
\hline 13 & $\begin{array}{l}\text { Dosen MK Metodologi Penelitian Saudara, mempunyai tingkat } \\
\text { pemahaman yang baik secara verbal, sehingga proses } \\
\text { perkuliahan anda terkesan menarik. }\end{array}$ & 0,766 & 0.380 & Valid \\
\hline 14 & $\begin{array}{l}\text { Dosen MK Metodologi Penelitian saudara, memiliki kecepatan } \\
\text { persepsi saat proses diskusi dan tanya jawab kepada } \\
\text { mahasiswa. }\end{array}$ & $\mathbf{0 , 8 4 1}$ & 0.380 & Valid \\
\hline 15 & $\begin{array}{l}\text { Dosen MK Metodologi Penelitian Saudara, memiliki fashion } \\
\text { tersendiri dalam memberikan kuliah, dan membuat sudut } \\
\text { pandang anda berubah menjadi lebih baik dalam melakukan } \\
\text { sebuah riset. }\end{array}$ & $\mathbf{0 , 8 4 7}$ & 0.380 & Valid \\
\hline
\end{tabular}




\begin{tabular}{|c|l|c|c|c|}
\hline No & \multicolumn{1}{|c|}{ Pernyataan Kompetensi Mahasiswa } & CITC & $\begin{array}{c}\text { R } \\
\text { tabel }\end{array}$ & Ket \\
\hline 16 & $\begin{array}{l}\text { Saat Perkuliahan MK Metodologi Penelitian, Dosen } \\
\text { mengarahkan kepada anda bagaimana menjaga hubungan yang } \\
\text { baik dengan rekan, dosen dan lingkungan/keadaaan sekitar } \\
\text { penelitian. }\end{array}$ & $\mathbf{0 . 3 8 0}$ & Valid \\
\hline 17 & $\begin{array}{l}\text { Saat Perkuliahan MK Metodologi Penelitian, Dosen } \\
\text { mengarahkan agar mahasiswa mempunyai tingkat kepekaan } \\
\text { yang tinggi dengan lingkungan/keadaan sekitar penelitian. }\end{array}$ & $\mathbf{0 , 8 2 2}$ & $\mathbf{0 . 3 8 0}$ & Valid \\
\hline 18 & $\begin{array}{l}\text { Saat Perkuliahan MK Metodologi Penelitian, Dosen } \\
\text { mengajarkan bagaimana menumbuhkan empati ketika meneliti. }\end{array}$ & $\mathbf{0 , 8 4 5}$ & $\mathbf{0 . 3 8 0}$ & Valid \\
\hline 19 & $\begin{array}{l}\text { Saat Perkuliahan MK Metodologi Penelitian, Dosen memberi } \\
\text { tahu pentingnya menjaga sensitivitas sosial yang berkenaan } \\
\text { dengan tema penelitian. }\end{array}$ & $\mathbf{0 , 8 7 6}$ & $\mathbf{0 . 3 8 0}$ & Valid \\
\hline 20 & $\begin{array}{l}\text { Saat Perkuliahan MK Metodologi Penelitian, Dosen memberi } \\
\text { tahu peneliti harus mempunyai sikap yang terbuka pada } \\
\text { lingkungannya. }\end{array}$ & $\mathbf{0 , 9 0 7}$ & $\mathbf{0 . 3 8 0}$ & Valid \\
\hline 21 & $\begin{array}{l}\text { Saat Perkuliahan MK Metodologi Penelitian, Dosen } \\
\text { Mengajarkan bagaimana bersikap fleksibel. }\end{array}$ & $\mathbf{0 , 9 4 8}$ & $\mathbf{0 . 3 8 0}$ & Valid \\
\hline 22 & $\begin{array}{l}\text { Saat Perkuliahan MK Metodologi Penelitian, Dosen } \\
\text { mengajarkan bagaimana menjalankan proses penelitian yang } \\
\text { terkadang terkesan menyulitkan. }\end{array}$ & $\mathbf{0 , 7 6 3}$ & $\mathbf{0 . 3 8 0}$ & Valid \\
\hline 23 & $\begin{array}{l}\text { Saat Perkuliahan MK Metodologi Penelitian, Dosen } \\
\text { mengajarkan bahwa dalam melakukan sebuah penelitian, } \\
\text { mahasiswa harus mempunyai visi di dalam dirinya. }\end{array}$ & $\mathbf{0 , 8 1 9}$ & $\mathbf{0 . 3 8 0}$ & Valid \\
\hline 24 & $\begin{array}{l}\text { Saat Perkuliahan MK Metodologi Penelitian, Dosen } \\
\text { memberikan contoh contoh tindakan yang tidak perlu } \\
\text { dilakukan saat proses penelitian berlangsung. }\end{array}$ & $\begin{array}{l}\mathbf{0 , 8 6 0} \\
\text { Saat Perkuliahan MK Metodologi Penelitian, Dosen memberi } \\
\text { tahu bahwa mahasiswa jangan takut dan ragu untuk selalu } \\
\text { bertanya mengenai perkembangan penelitiannya. }\end{array}$ & $\mathbf{0 . 3 8 0}$ & Valid \\
\hline : Pengalan & $\mathbf{0 . 3 8 0}$ & Valid \\
\hline
\end{tabular}

Sumber : Pengolahan Data, 2019

Berdasarkan output Validitas Data Variabel Kompetensi Mahasiswa Saat Menyusun Karya Ilmiah pada tabel 6 diatas diketahui dari 25 item dinyatakan valid karena nilai $r$ hitung lebih besar dari 0.3..

\section{B. Analisia Deskriptif}

\section{1) Frekuensi Responden item Tempat Kuliah}

Tabel 7 menjelaskan sebaran data tentang responden yang menanggapi item ini, terlihat sebaran data merata di semua tempat kuliah, yakni: sebanyak 150 responden/tempat kuliah.

Tabel 7. Frekunsi Item Tempat Kuliah

\begin{tabular}{|c|l|r|r|r|}
\hline \multicolumn{5}{|c|}{ Tempat Kuliah } \\
\hline \multicolumn{1}{|c|}{ Valid } & STIE MURA Lubuklinggau & Frequency & Percent & Valid Percent \\
\cline { 2 - 5 } & STMIK MURA Lubuklinggau & 150 & 25,0 & 25,0 \\
\cline { 2 - 5 } & STKIP PGRI Lubuklinggau & 150 & 25,0 & 25,0 \\
\cline { 2 - 5 } & Universitas Musi Rawas & 150 & 25,0 & 25,0 \\
\cline { 2 - 5 } & Total & 150 & 25,0 & 25,0 \\
\hline
\end{tabular}

Sumber : Pengolahan Data, 2019 


\section{2) Frekuensi Responden item Nilai MK Metodologi Penelitian}

Tabel 8 menjelaskan sebaran data tentang responden yang menanggapi item ini, terlihat sebaran data, yakni: sebanyak 238 responden memiliki nilai A MK Metodologi Penelitian; 221 responden memiliki nilai B MK Metodologi Penelitian; 41 responden belum menempuh MK Metodologi Penelitian; dan 96 responden sedang menempuh MK Metodologi Penelitian.

Tabel 8. Frekuensi Nilai MK Metodologi Penelitian

\begin{tabular}{|c|c|c|c|c|}
\hline \multicolumn{5}{|c|}{ Nilai MK Metodologi Penelitian } \\
\hline & & Frequency & Percent & $\begin{array}{c}\text { Valid } \\
\text { Percent }\end{array}$ \\
\hline \multirow[t]{6}{*}{ Valid } & & & & \\
\hline & A & 238 & 39,7 & 39,7 \\
\hline & $\mathrm{B}$ & 221 & 36,8 & 36,8 \\
\hline & Belum Menempuh & 41 & 6,8 & 6,8 \\
\hline & Sedang Menempuh & 96 & 16,0 & 16,0 \\
\hline & Total & 600 & 100,0 & 100,0 \\
\hline
\end{tabular}

Sumber : Pengolahan Data, 2019

\section{Uji Beda One Sample T Test}

1) Uji Beda One Sample $T$ Test Tempat kuliah dengan Variabel Metode Pembelajaran (MP; MP M; dan MP P)

Tabel 9 menjelaskan hasil uji beda untuk variabel tempat kuliah dengan sub-sub variabel di dalam variabel metode pembelajaran, sub-sub variabelnya terdiri dari: (1) Metode Pembelajaran; (2) Metode Pembelajaran Mikromorf; dan (3) Metode Pembelajaran Paramorf. Kriterianya adalah nilai sig. Deviation From linierity harus berada di bawah level alpha (5\% atau 0,05) dan nilai sig. Linierity harus diatas level alpha (5\% atau 0,05$)$. Hasilnya hanya model variabel tempat kuliah dengan sub variabel metode pembelajaran yang memenuhi kriteria, hal ini menunjukkan bahwa terdapat perbedaan pada model ini. Sedangkan sisa dua model lainnya tidak memenuhi kriteria, yang artinya tidak terdapat perbedaan.

Tabel 9. Uji Beda One Sample T Test Tempat kuliah dengan Variabel Metode Pembelajaran

\begin{tabular}{|l|l|l|r|c|c|}
\hline \multicolumn{5}{|c|}{ ANOVA Table } \\
\hline \multicolumn{2}{|c|}{} & Df & $\begin{array}{c}\text { Sig. } \\
\text { Linearity }\end{array}$ & $\begin{array}{c}\text { Sig. Deviation } \\
\text { from Linearity. }\end{array}$ \\
\hline \multirow{3}{*}{$\begin{array}{l}\mathrm{t} \\
\text { test }\end{array}$} & $\begin{array}{l}\text { Tempat } \\
\text { Kuliah }\end{array}$ & Tot Metode Pembelajaran & 18 & .106 & .000 \\
\cline { 2 - 5 } & & Tot MP Mikromorf & 1 & .000 & .000 \\
\cline { 2 - 5 } & Tot MP Paramorf & 17 & .000 & .000 \\
\cline { 2 - 5 } & Within Groups & 581 & & \\
\cline { 2 - 5 } & \multicolumn{2}{|l|}{ Total } & 599 & & \\
\hline
\end{tabular}

Sumber : Pengolahan Data, 2019 


\section{2). Uji Beda One Sample $T$ Test Tempat kuliah dengan Variabel} Kompetensi Mahasiswa (Kompetensi Intelektual; Kompetensi Pribadi; Kompetensi Fisik; Kompetensi Sosial; dan Kompetensi Spiritual)

Tabel 10 menjelaskan hasil uji beda untuk variabel tempat kuliah dengan sub-sub variabel di dalam variabel kompetensi, sub-sub variabelnya terdiri dari: (1) Kompetensi Intelektual; (2) Kompetensi Pribadi; (3) Kompetensi Fisik; (4) Kompetensi Sosial; dan (5) Kompetensi Spiritual. Kriterianya adalah nilai sig. Deviation From linierity harus berada di bawah level alpha $(5 \%$ atau 0,05$)$ dan nilai sig. Linierity harus diatas level alpha $(5 \%$ atau 0,05 ). Hasilnya hanya model variabel tempat kuliah dengan sub variabel Kompetensi Fisik yang memenuhi kriteria, hal ini menunjukkan bahwa terdapat perbedaan pada model ini. Sedangkan empat sisa model lainnya tidak memenuhi kriteria, yang artinya tidak terdapat perbedaan.

Tabel 10. Uji Beda One Sample T Test Tempat kuliah dengan Variabel Kompetensi Mahasiswa

\begin{tabular}{|c|c|c|c|c|c|}
\hline \multicolumn{6}{|c|}{ ANOVA Table } \\
\hline & & & $\mathrm{df}$ & $\begin{array}{c}\text { Sig. } \\
\text { Linearity }\end{array}$ & $\begin{array}{l}\text { Sig. Deviation } \\
\text { from Linearity. }\end{array}$ \\
\hline \multirow{7}{*}{$\begin{array}{l}\mathrm{t} \\
\text { test }\end{array}$} & \multirow{5}{*}{$\begin{array}{l}\text { Tempat } \\
\text { Kuliah }\end{array}$} & Tot Kompetensi Intelektual & 18 & .033 & .000 \\
\hline & & Tot Kompetensi Pribadi & 1 & .000 & .000 \\
\hline & & Tot Kompetensi Fisik & 17 & .078 & .000 \\
\hline & & Tot Kompetensi Sosial & & .002 & .000 \\
\hline & & Tot Kompetensi Spiritual & & .000 & .000 \\
\hline & \multicolumn{2}{|c|}{ Within Groups } & 581 & & \\
\hline & \multicolumn{2}{|c|}{ Total } & 599 & & \\
\hline
\end{tabular}

Sumber : Pengolahan Data, 2019

\section{E. Uji Beda Independent Sample T Test}

Tabel 11 menjelaskan hasil uji beda dengan uji Independent Sample T Test variabel Metode Pembelajaran dengan variabel Kompetensi Mahasiswa STIE MURA Lubuklinggau dengan mahasiswa STMIK MURA Lubuklinggau. Pengujian dilakukan pada masing masing sub variabel yang ada didalam variabel metode pembelajaran dan variabel kompetensi mahasiswa. Kriterianya adalah nilai sig test of equality of means harus berada di bawah level alpha (5\% atau 0,05), dengan demikian dapat dikatakan terdapat perbedaan untuk variabel yang termasuk dalam model ini. Hasilnya, baik untuk variabel metode pembelajaran dengan sub-sub variabelnya maupun untuk variabel kompetensi mahasiswa dengan sub-sub variabelnya tidak ada nilai sig test of equality of means yang berada di bawah 0,05 , artinya semua model dalam pengujian untuk mahasiwa STIE MURA dan mahasiswa STMIK MURA, tidak terdapat perbedaan. 
Tabel 11. Uji Beda Independent Sample T Test Variabel Metode Pembelajaran dengan Kompetensi Mahasiswa STIE MURA Lubuklinggau dengan STMIK MURA

Lubuklinggau

\begin{tabular}{|c|l|c|c|c|c|}
\hline \multicolumn{7}{|c|}{ Group Statistics dan Independent Samples Test } \\
\hline & Tempat Kuliah & $\mathrm{N}$ & Mean & \multicolumn{1}{c|}{ t-test for Equality of Means } \\
\hline \multirow{2}{*}{ Total MP } & STIE MURA Lubuklinggau & 150 & 24,71 &,- 014 & \multicolumn{1}{c|}{ Sig. (2-tailed) } \\
\cline { 2 - 6 } & STMIK MURA Lubuklinggau & 150 & 24,71 &,- 014 &, 989 \\
\hline \multirow{2}{*}{ Total MP M } & STIE MURA Lubuklinggau & 150 & 50,00 &, 633 &, 989 \\
\cline { 2 - 6 } & STMIK MURA Lubuklinggau & 150 & 49,37 &, 633 &, 527 \\
\hline \multirow{2}{*}{ Total MP P } & STIE MURA Lubuklinggau & 150 & 50,87 &, 322 &, 527 \\
\cline { 2 - 6 } & STMIK MURA Lubuklinggau & 150 & 50,58 &, 322 &, 748 \\
\hline \multirow{2}{*}{ Total KI } & STIE MURA Lubuklinggau & 150 & 21,45 &,- 705 &, 748 \\
\cline { 2 - 6 } & STMIK MURA Lubuklinggau & 150 & 21,95 &,- 705 &, 481 \\
\hline \multirow{2}{*}{ Total KP } & STIE MURA Lubuklinggau & 150 & 26,08 & 1,164 &, 481 \\
\cline { 2 - 6 } & STMIK MURA Lubuklinggau & 150 & 25,56 & 1,164 &, 245 \\
\hline \multirow{2}{*}{ Total KF } & STIE MURA Lubuklinggau & 150 & 25,53 &, 676 &, 245 \\
\cline { 2 - 6 } & STMIK MURA Lubuklinggau & 150 & 25,19 &, 676 &, 500 \\
\hline \multirow{2}{*}{ Total KS } & STIE MURA Lubuklinggau & 150 & 25,81 &, 806 &, 500 \\
\cline { 2 - 6 } & STMIK MURA Lubuklinggau & 150 & 25,43 &, 806 &, 421 \\
\hline \multirow{2}{*}{ Total KSP } & STIE MURA Lubuklinggau & 150 & 25,55 &, 166 &, 421 \\
\cline { 2 - 6 } & STMIK MURA Lubuklinggau & 150 & 25,47 &, 166 &, 868 \\
\hline \multirow{2}{*}{ Sumber } & &, 868 \\
\hline
\end{tabular}

Sumber : Pengolahan Data, 2019

Tabel 12 menjelaskan hasil uji beda dengan uji Independent Sample T Test pada variabel Metode Pembelajaran dengan variabel Kompetensi Mahasiswa STIE MURA Lubuklinggau dengan mahasiswa STKIP PGRI Lubuklinggau. Pengujian dilakukan terhadap masing masing sub variabel yang termasuk didalam variabel metode pembelajaran dan variabel kompetensi mahasiswa. Kriterianya adalah nilai sig test of equality of means harus berada di bawah level alpha (5\% atau 0,05), dengan demikian dapat dikatakan terdapat perbedaan untuk variabel yang termasuk dalam model ini. Hasilnya, baik untuk variabel metode pembelajaran dengan sub-sub variabelnya maupun untuk variabel kompetensi mahasiswa dengan sub-sub variabelnya semua nilai sig test of equality of means yang berada di bawah 0,05 , artinya semua model dalam pengujian untuk mahasiwa STIE MURA dan mahasiswa STKIP PGRI Lubuklinggau, terdapat perbedaan.

Tabel 12. Uji Beda Independent Sample T Test Variabel Metode Pembelajaran dengan Kompetensi Mahasiswa STIE MURA Lubuklinggau dengan STKIP PGRI

Lubuklinggau

\begin{tabular}{|c|l|c|c|c|r|}
\hline \multicolumn{7}{|c|}{ Group Statistics dan Independent Samples Test } \\
\hline & Tempat Kuliah & N & Mean & t-test for Equality of Means \\
\hline \multirow{2}{*}{ Total MP } & STIE MURA Lubuklinggau & 150 & 24,71 & $-12,965$ & Sig. (2-tailed) \\
\cline { 2 - 6 } & STKIP PGRI Lubuklinggau & 150 & 29,33 & $-12,965$ &, 000 \\
\hline \multirow{2}{*}{ Total MP M } & STIE MURA Lubuklinggau & 150 & 50,00 & $-4,785$ &, 000 \\
\cline { 2 - 6 } & STKIP PGRI Lubuklinggau & 150 & 53,83 & $-4,785$ &, 000 \\
\hline Total MP P & STIE MURA Lubuklinggau & 150 & 50,87 & $-5,050$ &, 000 \\
\hline
\end{tabular}




\begin{tabular}{|l|l|c|c|c|r|}
\hline \multicolumn{7}{|c|}{ Group Statistics dan Independent Samples Test } \\
\hline & Tempat Kuliah & $\mathrm{N}$ & Mean & \multicolumn{1}{c|}{ t-test for Equality of Means } \\
\hline & STKIP PGRI Lubuklinggau & 150 & 55,21 & $-5,050$ & Sig. (2-tailed) \\
\hline \multirow{3}{*}{ Total KI } & STIE MURA Lubuklinggau & 150 & 21,45 & $-10,093$ &, 000 \\
\cline { 2 - 6 } & STKIP PGRI Lubuklinggau & 150 & 27,27 & $-10,093$ &, 000 \\
\hline \multirow{2}{*}{ Total KP } & STIE MURA Lubuklinggau & 150 & 26,08 & $-2,978$ &, 000 \\
\cline { 2 - 6 } & STKIP PGRI Lubuklinggau & 150 & 27,43 & $-2,978$ &, 003 \\
\hline \multirow{2}{*}{ Total KF } & STIE MURA Lubuklinggau & 150 & 25,53 & $-5,622$ &, 003 \\
\cline { 2 - 6 } & STKIP PGRI Lubuklinggau & 150 & 27,87 & $-5,622$ &, 000 \\
\hline \multirow{2}{*}{ Total KS } & STIE MURA Lubuklinggau & 150 & 25,81 & $-4,970$ &, 000 \\
\cline { 2 - 6 } & STKIP PGRI Lubuklinggau & 150 & 27,87 & $-4,970$ &, 000 \\
\hline \multirow{2}{*}{ Total KSP } & STIE MURA Lubuklinggau & 150 & 25,55 & $-3,905$ &, 000 \\
\cline { 2 - 6 } & STKIP PGRI Lubuklinggau & 150 & 27,17 & $-3,905$ &, 000 \\
\hline
\end{tabular}

Sumber : Pengolahan Data, 2019

Tabel 13 menjelaskan hasil uji beda dengan uji Independent Sample T Test pada variabel Metode Pembelajaran dengan variabel Kompetensi Mahasiswa STIE MURA Lubuklinggau dengan mahasiswa Universitas Musi Rawas. Pengujian dilakukan terhadap masing masing sub variabel yang termasuk didalam variabel metode pembelajaran dan variabel kompetensi mahasiswa. Kriterianya adalah nilai sig test of equality of means harus berada di bawah level alpha (5\% atau 0,05), dengan demikian dapat dikatakan terdapat perbedaan untuk variabel yang termasuk dalam model ini. Hasilnya, hanya model dengan sub variabel kompetensi intelekual; model dengan sub variabel kompetensi fisik; dan model dengan sub variabel kompetensi sosial yang nilai sig test of equality of means berada diatas 0,05 , artinya tidak terdapat perbedaan. Sisa model lainnya baik untuk variabel metode pembelajaran dengan sub-sub variabelnya maupun untuk variabel kompetensi mahasiswa dengan sub-sub variabelnya semua nilai sig test of equality of means yang berada di bawah 0,05 , artinya semua model dalam pengujian untuk mahasiwa STIE MURA dan mahasiswa Universitas Musi Rawas, terdapat perbedaan.

Tabel 13. Uji Beda Independent Sample T Test Variabel Metode Pembelajaran dengan Kompetensi Mahasiswa STIE MURA Lubuklinggau dengan UNMURA

\begin{tabular}{|l|l|c|c|c|c|}
\hline \multicolumn{7}{|c|}{ Group Statistics dan Independent Samples Test } \\
\hline & Tempat Kuliah & $\mathrm{N}$ & Mean & t-test for Equality of Means \\
\hline \multirow{2}{*}{ Total MP } & STIE MURA Lubuklinggau & 150 & 24,71 & 3,309 & Sig. (2-tailed) \\
\cline { 2 - 6 } & Universitas Musi Rawas & 150 & 22,43 & 3,309 &, 001 \\
\hline \multirow{2}{*}{ Total MP M } & STIE MURA Lubuklinggau & 150 & 50,00 & 3,671 &, 001 \\
\cline { 2 - 6 } & Universitas Musi Rawas & 150 & 45,37 & 3,671 &, 000 \\
\hline \multirow{2}{*}{ Total MP P } & STIE MURA Lubuklinggau & 150 & 50,87 & 4,743 &, 000 \\
\cline { 2 - 6 } & Universitas Musi Rawas & 150 & 44,47 & 4,743 &, 000 \\
\hline \multirow{2}{*}{ Total KI } & STIE MURA Lubuklinggau & 150 & 21,45 &, 834 &, 000 \\
\cline { 2 - 6 } & Universitas Musi Rawas & 150 & 20,87 &, 834 &, 405 \\
\hline Total KP & STIE MURA Lubuklinggau & 150 & 26,08 & 4,642 &, 000 \\
\hline
\end{tabular}




\begin{tabular}{|l|l|l|l|l|r|}
\hline & Universitas Musi Rawas & 150 & 22,55 & 4,642 &, 000 \\
\hline \multirow{2}{*}{ Total KF } & STIE MURA Lubuklinggau & 150 & 25,53 & 1,049 &, 295 \\
\cline { 2 - 6 } & Universitas Musi Rawas & 150 & 25,15 & 1,049 &, 295 \\
\hline \multirow{2}{*}{ Total KS } & STIE MURA Lubuklinggau & 150 & 25,81 &,- 420 &, 674 \\
\cline { 2 - 6 } & Universitas Musi Rawas & 150 & 25,99 &,- 420 &, 674 \\
\hline \multirow{2}{*}{ Total KSP } & STIE MURA Lubuklinggau & 150 & 25,55 & 7,965 &, 000 \\
\cline { 2 - 6 } & Universitas Musi Rawas & 150 & 22,86 & 7,965 &, 000 \\
\hline
\end{tabular}

Sumber : Pengolahan Data, 2019

Tabel 14 menjelaskan hasil uji beda dengan uji Independent Sample T Test pada variabel Metode Pembelajaran dengan variabel Kompetensi Mahasiswa STMIK MURA Lubuklinggau dengan mahasiswa STKIP PGRI Lubuklinggau. Pengujian dilakukan terhadap masing masing sub variabel yang termasuk didalam variabel metode pembelajaran dan variabel kompetensi mahasiswa. Kriterianya adalah nilai sig test of equality of means harus berada di bawah level alpha (5\% atau 0,05), dengan demikian dapat dikatakan terdapat perbedaan untuk variabel yang termasuk dalam model ini. Hasilnya, baik untuk variabel metode pembelajaran dengan sub-sub variabelnya maupun untuk variabel kompetensi mahasiswa dengan sub-sub variabelnya semua nilai sig test of equality of means yang berada di bawah 0,05 , artinya semua model dalam pengujian untuk mahasiwa STMIK MURA dan mahasiswa STKIP PGRI Lubuklinggau, terdapat perbedaan.

Tabel 14. Uji Beda Independent Sample T Test Variabel Metode Pembelajaran dengan Kompetensi Mahasiswa STMIK MURA Lubuklinggau dengan STKIP PGRI

Lubuklinggau

\begin{tabular}{|c|l|c|c|c|r|}
\hline \multicolumn{7}{|c|}{ Group Statistics dan Independent Samples Test } \\
\hline & Tempat Kuliah & $\mathrm{N}$ & Mean & $\mathrm{t}$-test for Equality of Means \\
\hline \multirow{2}{*}{ Total MP } & STMIK MURA Lubuklinggau & 150 & 24,71 & $-12,527$ & Sig. (2-tailed) \\
\cline { 2 - 6 } & STKIP PGRI Lubuklinggau & 150 & 29,33 & $-12,527$ &, 000 \\
\hline \multirow{2}{*}{ Total MP M } & STMIK MURA Lubuklinggau & 150 & 49,37 & $-5,396$ &, 000 \\
\cline { 2 - 6 } & STKIP PGRI Lubuklinggau & 150 & 53,83 & $-5,396$ &, 000 \\
\hline \multirow{2}{*}{ Total MP P } & STMIK MURA Lubuklinggau & 150 & 50,58 & $-5,305$ &, 000 \\
\cline { 2 - 6 } & STKIP PGRI Lubuklinggau & 150 & 55,21 & $-5,305$ &, 000 \\
\hline \multirow{2}{*}{ Total KI } & STMIK MURA Lubuklinggau & 150 & 21,95 & $-9,570$ &, 000 \\
\cline { 2 - 6 } & STKIP PGRI Lubuklinggau & 150 & 27,27 & $-9,570$ &, 000 \\
\hline \multirow{3}{*}{ Total KP } & STMIK MURA Lubuklinggau & 150 & 25,56 & $-3,950$ &, 000 \\
\cline { 2 - 6 } & STKIP PGRI Lubuklinggau & 150 & 27,43 & $-3,950$ &, 000 \\
\hline \multirow{2}{*}{ Total KF } & STMIK MURA Lubuklinggau & 150 & 25,19 & $-6,009$ &, 000 \\
\cline { 2 - 6 } & STKIP PGRI Lubuklinggau & 150 & 27,87 & $-6,009$ &, 000 \\
\hline \multirow{2}{*}{ Total KS } & STMIK MURA Lubuklinggau & 150 & 25,43 & $-5,889$ &, 000 \\
\cline { 2 - 6 } & STKIP PGRI Lubuklinggau & 150 & 27,87 & $-5,889$ &, 000 \\
\hline \multirow{2}{*}{ Total KSP } & STMIK MURA Lubuklinggau & 150 & 25,47 & $-4,183$ &, 000 \\
\cline { 2 - 6 } & STKIP PGRI Lubuklinggau & 150 & 27,17 & $-4,183$ &, 000 \\
\hline
\end{tabular}

Sumber : Pengolahan Data, 2019 
Tabel 15 menjelaskan hasil uji beda dengan uji Independent Sample T Test pada variabel Metode Pembelajaran dengan variabel Kompetensi Mahasiswa STMIK MURA Lubuklinggau dengan mahasiswa Universitas Musi Rawas. Pengujian dilakukan terhadap masing masing sub variabel yang termasuk didalam variabel metode pembelajaran dan variabel kompetensi mahasiswa. Kriterianya adalah nilai sig test of equality of means harus berada di bawah level alpha (5\% atau 0,05), dengan demikian dapat dikatakan terdapat perbedaan untuk variabel yang termasuk dalam model ini. Hasilnya, hanya model dengan sub variabel kompetensi intelekual; model dengan sub variabel kompetensi fisik; dan model dengan sub variabel kompetensi sosial yang nilai sig test of equality of means berada diatas 0,05 , artinya tidak terdapat perbedaan. Sisa model lainnya baik untuk variabel metode pembelajaran dengan sub-sub variabelnya maupun untuk variabel kompetensi mahasiswa dengan sub-sub variabelnya semua nilai sig test of equality of means yang berada di bawah 0,05 , artinya semua model dalam pengujian untuk mahasiwa STMIK MURA dan mahasiswa Universitas Musi Rawas, terdapat perbedaan.

Tabel 15. Uji Beda Independent Sample T Test Variabel Metode Pembelajaran dengan Kompetensi Mahasiswa STMIK MURA Lubuklinggau dengan UNMURA

\begin{tabular}{|l|l|c|c|c|c|}
\hline \multicolumn{7}{|c|}{ Group Statistics dan Independent Samples Test } \\
\hline & Tempat Kuliah & $\mathrm{N}$ & Mean & $\mathrm{t}$-test for Equality of Means \\
\hline \multirow{3}{*}{ Total MP } & STMIK MURA Lubuklinggau & 150 & 24,71 & 3,289 & Sig. (2-tailed) \\
\cline { 2 - 6 } & Universitas Musi Rawas & 150 & 22,43 & 3,289 &, 001 \\
\hline \multirow{2}{*}{ Total MP M } & STMIK MURA Lubuklinggau & 150 & 49,37 & 3,134 &, 001 \\
\cline { 2 - 6 } & Universitas Musi Rawas & 150 & 45,37 & 3,134 &, 002 \\
\hline \multirow{2}{*}{ Total MP P } & STMIK MURA Lubuklinggau & 150 & 50,58 & 4,496 &, 002 \\
\cline { 2 - 6 } & Universitas Musi Rawas & 150 & 44,47 & 4,496 &, 000 \\
\hline \multirow{2}{*}{ Total KI } & STMIK MURA Lubuklinggau & 150 & 21,95 & 1,593 &, 000 \\
\cline { 2 - 6 } & Universitas Musi Rawas & 150 & 20,87 & 1,593 &, 112 \\
\hline \multirow{2}{*}{ Total KP } & STMIK MURA Lubuklinggau & 150 & 25,56 & 3,896 &, 000 \\
\cline { 2 - 6 } & Universitas Musi Rawas & 150 & 22,55 & 3,896 &, 000 \\
\hline \multirow{3}{*}{ Total KF } & STMIK MURA Lubuklinggau & 150 & 25,19 &, 118 &, 906 \\
\cline { 2 - 6 } & Universitas Musi Rawas & 150 & 25,15 &, 118 &, 906 \\
\hline \multirow{2}{*}{ Total KS } & STMIK MURA Lubuklinggau & 150 & 25,43 & $-1,297$ &, 196 \\
\cline { 2 - 6 } & Universitas Musi Rawas & 150 & 25,99 & $-1,297$ &, 196 \\
\hline \multirow{2}{*}{ Total KSP } & STMIK MURA Lubuklinggau & 150 & 25,47 & 8,050 &, 000 \\
\cline { 2 - 6 } & Universitas Musi Rawas & 150 & 22,86 & 8,050 &, 000 \\
\hline
\end{tabular}

Sumber : Pengolahan Data, 2019

Tabel 16 menjelaskan hasil uji beda dengan uji Independent Sample T Test pada variabel Metode Pembelajaran dengan variabel Kompetensi Mahasiswa STKIP PGRI Lubuklinggau dengan mahasiswa Universitas Musi Rawas. Pengujian dilakukan terhadap masing masing sub variabel yang termasuk didalam variabel metode pembelajaran dan variabel kompetensi 
mahasiswa. Kriterianya adalah nilai sig test of equality of means harus berada di bawah level alpha (5\% atau 0,05), dengan demikian dapat dikatakan terdapat perbedaan untuk variabel yang termasuk dalam model ini. Hasilnya, baik untuk variabel metode pembelajaran dengan sub-sub variabelnya maupun untuk variabel kompetensi mahasiswa dengan sub-sub variabelnya semua nilai sig test of equality of means yang berada di bawah 0,05 , artinya semua model dalam pengujian untuk mahasiwa STKIP PGRI Lubuklinggau dan mahasiswa Universitas Musi Rawas, terdapat perbedaan.

Tabel 16. Uji Beda Independent Sample T Test Variabel Metode Pembelajaran dengan Kompetensi Mahasiswa STKIP PGRI Lubuklinggau dengan UNMURA

\begin{tabular}{|c|c|c|c|c|c|}
\hline \multicolumn{6}{|c|}{ Group Statistics } \\
\hline & Tempat Kuliah & $\mathrm{N}$ & Mean & $\mathrm{t}$ & Sig. (2-tailed) \\
\hline \multirow[t]{2}{*}{ Total MP } & $\begin{array}{l}\text { STKIP PGRI Lubuklinggau } \\
\end{array}$ & 150 & 29,33 & 11,378 &, 000 \\
\hline & Universitas Musi Rawas & 150 & 22,43 & 11,378 & 000 \\
\hline \multirow[t]{2}{*}{ Total MP M } & STKIP PGRI Lubuklinggau & 150 & 53,83 & 7,448 & 000 \\
\hline & Universitas Musi Rawas & 150 & 45,37 & 7,448 & 000 \\
\hline \multirow[t]{2}{*}{ Total MP P } & STKIP PGRI Lubuklinggau & 150 & 55,21 & 8,107 &, 000 \\
\hline & Universitas Musi Rawas & 150 & 44,47 & 8,107 &, 000 \\
\hline \multirow[t]{2}{*}{ Total KI } & STKIP PGRI Lubuklinggau & 150 & 27,27 & 11,896 &, 000 \\
\hline & Universitas Musi Rawas & 150 & 20,87 & 11,896 &, 000 \\
\hline \multirow[t]{2}{*}{ Total KP } & STKIP PGRI Lubuklinggau & 150 & 27,43 & 6,286 & ,000 \\
\hline & Universitas Musi Rawas & 150 & 22,55 & 6,286 & ,000 \\
\hline \multirow[t]{2}{*}{ Total KF } & STKIP PGRI Lubuklinggau & 150 & 27,87 & 9,247 & ,000 \\
\hline & Universitas Musi Rawas & 150 & 25,15 & 9,247 & ,000 \\
\hline \multirow[t]{2}{*}{ Total KS } & STKIP PGRI Lubuklinggau & 150 & 27,87 & 5,036 & ,000 \\
\hline & Universitas Musi Rawas & 150 & 25,99 & 5,036 & ,000 \\
\hline \multirow[t]{2}{*}{ Total KSP } & STKIP PGRI Lubuklinggau & 150 & 27,17 & 14,842 & 000 \\
\hline & Universitas Musi Rawas & 150 & 22,86 & 14,842 &, 000 \\
\hline
\end{tabular}

Sumber : Pengolahan Data, 2019

\section{F. Uji Beda One Way Anova}

\section{1) Uji Beda One Way Anova Variabel Metode Pembelajaran}

Uji beda one way anova dapat dilakukan apabila memenuhi kriteria pengujian homogenitas sebelumnya. Nilai sig yang dihasilkan oleh variabel Metode Pembelajaran yang terdiri dari sub variabel Metode Pembelajaran Mikromorf dan sub variabel Metode Pembelajaran Paramorf harus berada dibawah level aplha $(0,05)$, sehingga syarat homogenitasnya terpenuh. Nilai yang dikeluarkan pada tabel 17 menghasilkan nilai sig dibawah 0.05. yang artiny baik sub variabel Metode Pembelajaran Mikromorf, maupun sub variabel Metode Pembelajaran Paramorf memenuhi syarat.

Tabel 17. Test of Homogenity Variabel Metode Pembelajaran

\begin{tabular}{|l|c|c|c|c|}
\hline \multicolumn{5}{|c|}{ Test of Homogeneity of Variances } \\
\hline & Levene Statistic & df1 & df2 & Sig. \\
\hline Total MP M & $60,652^{\mathrm{a}}$ & 17 & 581 &, 000 \\
\hline Total MP P & $109,465^{\mathrm{b}}$ & 17 & 581 &, 000 \\
\hline
\end{tabular}


a. Groups with only one case are ignored in computing the test of homogeneity of variance for Total MP M.

b. Groups with only one case are ignored in computing the test of homogeneity of variance for Total MP P.

Sumber : Pengolahan Data, 2019

Tabel 18 menjelaskan hasil pengujian dengan teknik one way anova, kriterianya adalah apabila nilai sig yang dihasilkan di tabel berada dibawah level alpha $(5 \%$ atau 0,05$)$ maka dapatdikatakan terdapat perbedaan di dalam variabel metode pembelajaran di masing-masing PTS Hasilnya menunjukkan bahwa nilai sig sebesar 0,000 yang berarti nilai tersebut berada dibwah level 0,05, dengan demikian dapat dikatakan tredapat perbedaan metode pembelajaran di masing-masing PTS.

Tabel 18. Uji Beda One Way Anova Variabel Metode Pembelajaran

\begin{tabular}{|l|l|r|r|r|r|c|}
\hline \multicolumn{2}{|c|}{ ANOVA } & \multicolumn{1}{c|}{$\begin{array}{c}\text { Sum of } \\
\text { Squares }\end{array}$} & df & $\begin{array}{c}\text { Mean } \\
\text { Square }\end{array}$ & F & Sig. \\
\hline \multirow{2}{*}{$\begin{array}{l}\text { Total MP } \\
\text { M }\end{array}$} & $\begin{array}{l}\text { Between } \\
\text { Groups }\end{array}$ & 47931,991 & 18 & 2662,888 & 188,001 &, 000 \\
\cline { 2 - 7 } & Within Groups & 8229,394 & 581 & 14,164 & & \\
\cline { 2 - 7 } & Total & 56161,385 & 599 & & & \\
\hline \multirow{3}{*}{ Total MP P } & $\begin{array}{l}\text { Between } \\
\text { Groups }\end{array}$ & 54730,303 & 18 & 3040,572 & 148,707 &, 000 \\
\cline { 2 - 8 } & Within Groups & 11879,531 & 581 & 20,447 & & \\
\cline { 2 - 8 } & Total & 66609,833 & 599 & & & \\
\hline
\end{tabular}

Sumber : Pengolahan Data, 2019

\section{2) Uji Beda One Way Anova Variabel Kompetensi Mahasiswa}

Uji beda one way anova dapat dilakukan apabila memenuhi kriteria pengujian homogenitas sebelumnya. Nilai sig yang dihasilkan oleh variabel Kompetensi Mahasiswa yang terdiri dari sub variabel Kompetensi Intelektual; Kompetensi Pribadi; Kompetensi Fisik; Kompetensi Sosial; dan Kompetensi Spiritual harus berada dibawah level aplha $(0,05)$, sehingga syarat homogenitasnya terpenuh. Nilai yang dikeluarkan pada tabel 19 menghasilkan nilai sig dibawah 0.05. yang artinya semua sub variabel Kompetensi Mahasiswa memenuhi syarat.

Tabel 19. Test of Homogenity Variabel Kompetensi Mahasiswa

\begin{tabular}{|l|r|r|r|r|}
\hline \multicolumn{5}{|c|}{ Test of Homogeneity of Variances } \\
\hline & Levene Statistic & df1 & df2 & \multicolumn{1}{|c|}{ Sig. } \\
\hline Total KI & $20,823^{\mathrm{a}}$ & 17 & 581 &, 000 \\
\hline Total KP & $80,613^{\mathrm{b}}$ & 17 & 581 &, 000 \\
\hline Total KF & $54,336^{\mathrm{c}}$ & 17 & 581 &, 000 \\
\hline Total KS & $113,631^{\mathrm{d}}$ & 17 & 581 &, 000 \\
\hline Total KSP & $55,048^{\mathrm{e}}$ & 17 & 581 &, 000 \\
\hline a. Groups with only one case are ignored in computing the test of homogeneity of variance for Total \\
\hline
\end{tabular}






Sumber : Pengolahan Data, 2019

Tabel 20 menjelaskan hasil pengujian dengan teknik one way anova, kriterianya adalah apabila nilai sig yang dihasilkan di tabel berada dibawah level alpha $(5 \%$ atau 0,05$)$ maka dapatdikatakan terdapat perbedaan di dalam variabel kompetensi mahasiswa di masing-masing PTS. Hasilnya menunjukkan bahwa nilai sig sebesar 0,000 yang berarti nilai tersebut berada dibawah level 0,05 , dengan demikian dapat dikatakan tredapat perbedaan kompetensi mahasiswa di masing-masing PTS.

Tabel 20. Uji Beda One Way Anova Variabel Kompetensi Mahasiswa

\begin{tabular}{|c|c|c|c|c|c|c|}
\hline \multicolumn{7}{|c|}{ ANOVA } \\
\hline & & Sum of Squares & $\mathrm{df}$ & Mean Square & $\mathrm{F}$ & Sig. \\
\hline \multirow[t]{3}{*}{ Total KI } & Between Groups & 12130,042 & 18 & 673,891 & 41,265 &, 000 \\
\hline & Within Groups & 9488,251 & 581 & 16,331 & & \\
\hline & Total & 21618,293 & 599 & & & \\
\hline \multirow[t]{3}{*}{ Total KP } & Between Groups & 15775,395 & 18 & 876,411 & 125,313 & ,000 \\
\hline & Within Groups & 4063,379 & 581 & 6,994 & & \\
\hline & Total & 19838,773 & 599 & & & \\
\hline \multirow[t]{3}{*}{ Total KF } & Between Groups & 4567,201 & 18 & 253,733 & 41,233 & 000 \\
\hline & Within Groups & 3575,264 & 581 & 6,154 & & \\
\hline & Total & 8142,465 & 599 & & & \\
\hline \multirow[t]{3}{*}{ Total KS } & Between Groups & 4754,359 & 18 & 264,131 & 41,328 &, 000 \\
\hline & Within Groups & 3713,266 & 581 & 6,391 & & \\
\hline & Total & 8467,625 & 599 & & & \\
\hline \multirow[t]{3}{*}{ Total KSP } & Between Groups & 4206,612 & 18 & 233,701 & 39,245 &, 000 \\
\hline & Within Groups & 3459,782 & 581 & 5,955 & & \\
\hline & Total & 7666,393 & 599 & & & \\
\hline
\end{tabular}

Sumber : Pengolahan Data, 2019

\section{PEMBAHASAN}

\section{1) Metode Pembelajaran dan Kompetensi Mahasiswa.}

Semua instrumen dalam penelitian ini tergolong valid dan semua variabel tergolong reliabel, hal itu dapat dibuktikan melalu tabel 4; tabel 5; dan tabel 6, hal ini membuktikan (Prince \& Felder, 2006) bahwa instrumen dapat dikatakan sebagai instrumen yang sah dan dipercaya dalam mengukur konsep metode pembelajaran dan konsep kompetensi mahasiswa di penelitian ini. 
Apabila melihat nilai korelasi yang dihasilkan berdasarkan kriteria korelasi secara umum, maka secara konsep reliabilitas, konsep kompetensi mahasiswa memiliki keeratan yang paling besar, dan apabila dilihat dari nilai item di validitas konsep metode pembelajaran maka nilai korelasi item "Saat memberikan kuliah. Dosen MK Metodologi Penelitian Saudara, memberikan contoh Proposal Penelitian dan Hasil Akhir Karya Ilmiah yang lengkap" memiliki nilai yang paling tinggi. Kemudian untuk item di validitas konsep kompetensi mahasiswa, nilai korelasi yang paling tinggi ada pada item "Saat Perkuliahan MK Metodologi Penelitian, Dosen Mengajarkan bagaimana bersikap fleksibel".

Temuan itu menunjukkan bahwa di mahasiswa merasakan bagaimana dosen memberikan perkuliahan di MK Metodologi penelitian dengan benarbenar memberikan contoh (Ramsden, 2003), dan dosen mengajarkan bagaimana mereka bersikap fleksibel, sebagaimana sikap yang paling disukai oleh mahasiswa.

\section{2) Perbedaan Metode Pembelajaran}

Mahasiswa umumnya memiliki standar dalam menilai bagaimana dosennya memberikan perkuliahan dikelas (Biggs, 1987), standar itu kadang merupakan standar yang tidak resmi, seperti: (1) sikap santai dosen; (2) sikap realistik dosen; dan (3) mudahnya dosen memberikan nilai yang bagus kepada mahasiswa. Apabila dilihat dari sisi bagaimana dosen memberikan perkuliahan dengan menerapkan metode pembelajaran dengan standar yang benar, maka dapat dikatakan dosen tersebut beresiko menjadi dosen yang tidak populer.

Riset ini menjelaskan bagaimana proses penerapan metode pembelajaran dengan pendekatan model paramorf dan model mikromorf di 4 PTS yakni: STIE MURA; STMIK MURA; STKIP PGRI Lubuklinggau; dan Universitas Musi Rawas (lihat tabel 9), secara umum metode pembelajaran yang diterapkan terdapat perbedaan, namun tidak ada perbedaaan ketika metode pembelajaran tersebut dilakukan dengan menerapkan metode yang lebih spesifik, (seperti model paramorf dan mikromorf), perbedaan bisa saja terjadi dikarenakan adanya standar yang berbeda pada tiap PTS, seperti:

1. Standar dalam pembuatan rencana pembelajarannya;

2. Model/teknik/cara dalam melaksanakan perkuliahannya;

3. Buku teori yang digunakan;

4. Penggunaan jurnal ilmiah; dan

5. Fasilitas dalam melaksanakan Perkuliahan. 
Namun ketika model pembelajaran diterapkan secara khusus, yakni dengan menerapkan spesifik model (seperti model paramorf dan mikromorf) maka yang terjadi tidak terdapat perbedaan, ini berarti mungkin dosen di tiap PTS memang membedakan standar mereka, namun ketika sudah kearah teknis pembelajaran, semua dosen yang mengajar MK metodologi di empat PTS ini memiliki kesamaan/pola yang menyerupai, hal ini bisa merupakan temuan yang menarik karena akan memberikan dua makna, yakni: (1) setiap dosen memiliki standar yang sama, ini memperlihatkan bahwa tujuan akhir dari memberikan kuliah Mk ini adalah sama, misal: kewajiban tiap riset yang harus dipublikasikan. (2) hal ini menunjukkan dosen tidak memiliki inovasi dan pengembangan model mereka sendiri dalam memberikan perkuliahan.

\section{3) Perbedaan Kompetensi Mahasiswa}

Kompetensi mahasiswa sebenarnya dapat melalui banyak hal, teruatam untuk bidang pengajaran (Bonwell \& Eison, 1991), namun dalam hal ini penulis hanya melihat dari perspektif 3 hal, yakni: (1) nilai akademisnya (IPK); (2) kualitas karya ilmiahnya (publikasi); dan (3) tempat mahasiswa itu bekerja setelah lulus.

Ukuran pertama, nilai akademis (IPK), ukuran item ini sangat luas, karena semua indikator baik sejak masuk kuliah, hingga tamat menjadi pertimbangan, ukuran ini hanya bisa di teliti dengan waktu yang lama; ukuran ketiga, tempat mahasiswa bekerja setelah lulus, merupakan forecasting, dan hal ini juga susah diukur; hal yang paling mungkin diukur adalah dengan melihat ukuran yang kedua, yakni tentang kualitas karya ilmiahnya (misal karya ilmiahnya terbit di jurnal yang bereputasi Q1, Q2, Q3, dana atau Q4), peneliti melihat ukuran ini dapat dilihat dari kompetensi mahasiswa, baik dari sisi intelektual, pribadi, fisik, sosial, maupun spiritual.

Hasilnya hanya model variabel tempat kuliah dengan sub variabel Kompetensi Fisik yang memenuhi kriteria, hal ini menunjukkan bahwa terdapat perbedaan pada model ini. Sedangkan empat sisa model lainnya tidak memenuhi kriteria, yang artinya tidak terdapat perbedaan.

Perbedaaan pada kompetensi fisik mahasiswa di empat PTS menjadi temuan bahwa dosen MK metodologi penelitian benar-benar menjadi ujung tombak tempat mengasah mahasiswa agar mampu dalam menyusun karya ilmiahnya. Karena dapat dikatakan dosen MK metodologi penelitian menjadi leading factor/centralism mahasiswa yang menjadi panutan mahasiswa untuk mampu mempublikasikan karya ilmiahnya.

\section{PENUTUP \\ Simpulan}

Uraian pada hasil dan pembahasan dapat disimpulkan bahwa terdapat perbedaan pada tiap PTS dalam penerapan model pembelajaran secara umum 
dan secara spesifik baik pendekatan paramof dan pendekatan mikromof. Sedangkan pada kompetensi fisik, adanya perbedaan pada tiap mahasiswa antar perguruan tinggi. Pada sisi yang lain seperti kompetensi intelektual, pribadi, social dan spiritual tidak ditemukan perbedaan antar mahasiswa.

\section{Saran}

Dari hasil penelitian ini peneliti menyarankan sebaiknya tiap perguruan tinggi memiliki standar yang sama dalam penerapan model pembelajaran, dengan varian pada spesifik model sesuai dengan kriteria/demografi mahasiswanya. Pada sisi yang lain kompetensi mahasiswa hendaknya dibangun tidak hanya berdasarkan kajian akademis, untuk itu tiap perguruan tinggi hendaknya memperhatikan tindakan dalam kehidupan sosial dan aspek spiritual.

\section{DAFTAR PUSTAKA}

Biggs, J. B. (1987). Student Approaches to Learning and Studying. Research Monograph: ERIC.

Bonwell, C. C., \& Eison, J. A. (1991). Active Learning: Creating Excitement in the Classroom. 1991 ASHE-ERIC Higher Education Reports: ERIC.

Derlaga, V. J., \& Berg, J. H. (1987). Self-disclosure: Theory, research, and therapy: Springer Science \& Business Media.

Effendi, M. (2016). Integrasi Pembelajaran Active Learning dan InternetBased Learning dalam Meningkatkan Keaktifan dan Kreativitas Belajar. Nadwa, 7(2), 283-309.

Hamdi, A. S., \& Bahruddin, E. (2015). Metode penelitian kuantitatif aplikasi dalam pendidikan: Deepublish.

Irham, F. (2016). Pengantar Manajemen Sumber Daya Manusia Konsep \& Kinerja. Edisi Pertama. Jakarta (ID): Mitra Wacana Media.

Kasmadi, N. S. S. (2014). Panduan modern penelitian kuantitatif. Bandung: Alfabeta.

Kunandar, G. P. I. K. T. (2007). Satuan Pendidikan (KTSP) dan Persiapan Menghadapi Sertifikasi Guru. Jakarta: PT Raja Grafindo Persada.

Mazur, E. (2009). Farewell, lecture? Science, 323(5910), 50-51.

Oka, G. P. A. (2017). Model Konseptual Pengembangan Produk Pembelajaran: Disertai Teknik Evaluasi: Arya Oka.

Özdemir, D. (2016). Applied statistics for economics and business: Springer.

Prince, M. J., \& Felder, R. M. (2006). Inductive teaching and learning methods: Definitions, comparisons, and research bases. Journal of engineering education, 95(2), 123-138.

Purnomo, E. A., \& Mawarsari, V. D. (2014). Peningkatan kemampuan pemecahan masalah melalui model pembelajaran ideal problem 
solving berbasis project based learning. Jurnal Karya Pendidikan Matematika, 1(1).

Ramsden, P. (2003). Learning to teach in higher education: Routledge.

Saputri, A. A., \& Wilujeng, I. (2017). Developing Physics E-Scaffolding Teaching Media to Increase the Eleventh-Grade Students' Problem Solving Ability and Scientific Attitude. International Journal of Environmental and Science Education, 12(4), 729-745.

Saryatun, S. (2015). Studi Perbandingan Kompetensi Praktik Kelistrikan Otomotif Mahasiswa Lulusan Sma Dan Smk Pada Program Studi Pendidikan Teknik Mesin Jptk Fkip Uns. Jurnal Nosel, 3(4).

Sedarmayanti, H. (2018). Manajemen Sumber Daya Manusia; Reformasi Birokrasi dan Manajemen Pegawai Negeri Sipil: Reflika Aditama.

Sedarmayanti, M., \& Pd, M. (2001). Sumber daya manusia dan produktivitas kerja. Bandung: CV. Mandar Maju.

Sedarmayanti, P. (2007). Manajemen Sumber Daya Manusia. Jakarta: PT. Bumi Aksara.

Situmorang, A. S. (2014). Desain Model Pembelajaran Based Learning

Dalam Peningkatan Kemampuan Konsep Mahasiswa Semester Tiga Jurusan Pendidikan Matematika FKIP-UHN Medan. JURNAL SULUH PENDIDIKAN.

Sugiyono, D. (2006). Statistika untuk penelitian. Bandung: CV. Alfabeta.

Sugiyono, P. (2005). Memahami penelitian kualitatif. Bandung: Alfabeta.

Sugiyono, P. (2015). Metode penelitian kombinasi (mixed methods). Bandung: Alfabeta.

Undang Undang Republik Indonesia, Nomor : 20/2003. Tentang Sisdiknas penjelasan pasal 35 (1). (2003).

Wahyudi, S. T. (2017). Statistika ekonomi konsep, teori dan penerapan: Universitas Brawijaya Press.

Zendrato, J. (2016). Tingkat Penerapan Rencana Pelaksanaan Pembelajaran dalam Pelaksanaan Pembelajaran di Kelas Suatu Studi Kasus di SMA Dian Harapan Jakarta. Scholaria: Jurnal Pendidikan Dan Kebudayaan, 6(2), 58-73.

Zulpadrianto, Z., \& Husna, H. (2015). Perbandingan Kompetensi Mahasiswa Yang Diberi Resitasi Peta Konsep Dengan Menjawab Pertanyaan Sebelum Melaksanakan Praktikum Fisika Dasar Di Laboratorium Fisika Dasar Stkip Pgri Sumatera Barat. Jurnal Riset Fisika Edukasi dan Sains(Vol 2, No 1 (2015): Jurnal Riset Fisika Edukasi dan Sains), 42-54. 
172| Fokus : Jurnal Kajian Keislaman dan Kemasyarakatan, Vol 4, No. 2, Nov 2019 